\title{
A brief account of Julius Planer's life and research
}

\author{
R. Bilyy 12 , A. Lutsyk \\ ${ }^{1}$ Institute of Cell Biology, National Academy of Sciences of Ukraine, Lviv, Ukraine \\ 2 Danylo Halytskyi Lviv National Medical University, Lviv, Ukraine
}

Received August 17, 2010, in final form September 16, 2010

\begin{abstract}
A brief account of the life and research activities of Julius Planer is presented. Professor Planer is a scientist who lived one and half century ago. However, his studies, in particular, during the years when he headed Department of Anatomy at Universität in Lemberg, nowadays known as the Ivan Franko National University of Lviv in Ukraine, were essential to a modern understanding of liquid crystals. While working at Lviv University, Planer also made several landmark contributions to biomedical science.
\end{abstract}

Key words: Julius Planer, liquid crystal, history of science

PACS: $01.65 .+9$

Julius Planer is an outstanding scientist who greatly contributed to modern understanding of liquid crystals as well as malaria. Unfortunately, we do not know much of his biography. The present note, to the best of our knowledge, is the first attempt to introduce this fellow-man to a wide audience of a condensed matter community as well as to those who are interested in the history of science. Julius Planer (Julius Planer von Plan) was born on August 13, 1827 in Vienna, Austria, where he obtained medical education and started his work in a famous Viennese pathologico-anatomical school. In particular, from 1845 till 1849 he attended Medical faculty of Vienna University and later during years 1850-1854 he took position of the first assistant of Prof. Carl von Rokitansky 1 in Vienna [1, 2]. In 1951 Julius Planer obtained the title of Professor of Anatomy and Physiology. During this period, his first known scientific works were published [3, 4].

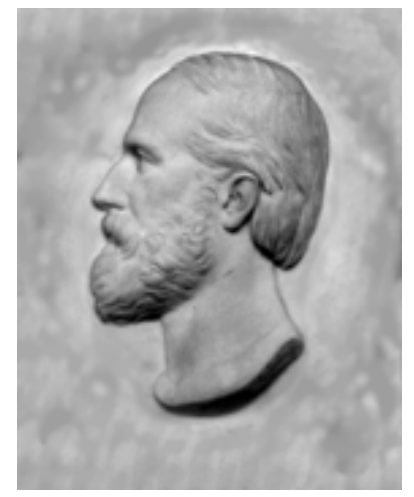

Figure 1. The bas-relief of Prof. Planer at University of Graz taken from [5].

In 1855 Julius Planer came to Lviv 2 where during 1855-1863 he headed the Department of Anatomy at University in Lviv [6]. The Lviv University has a long history dating back to 1661 and

\footnotetext{
${ }^{1}$ Rokitansky is a founder of Viennese pathologico-anatomical school.

${ }^{2}$ City of Lviv was known as Lemberg in Austrian Empire.
} 
the details on this can be found elsewhere [7]. Since 1851 until 1891, i. e. the years that include the time period when Julius Planer stayed in Lviv, University was located in the only building at Mykolai Street, now Hrushevskyy Street, 4 (see the photography in figure 2).

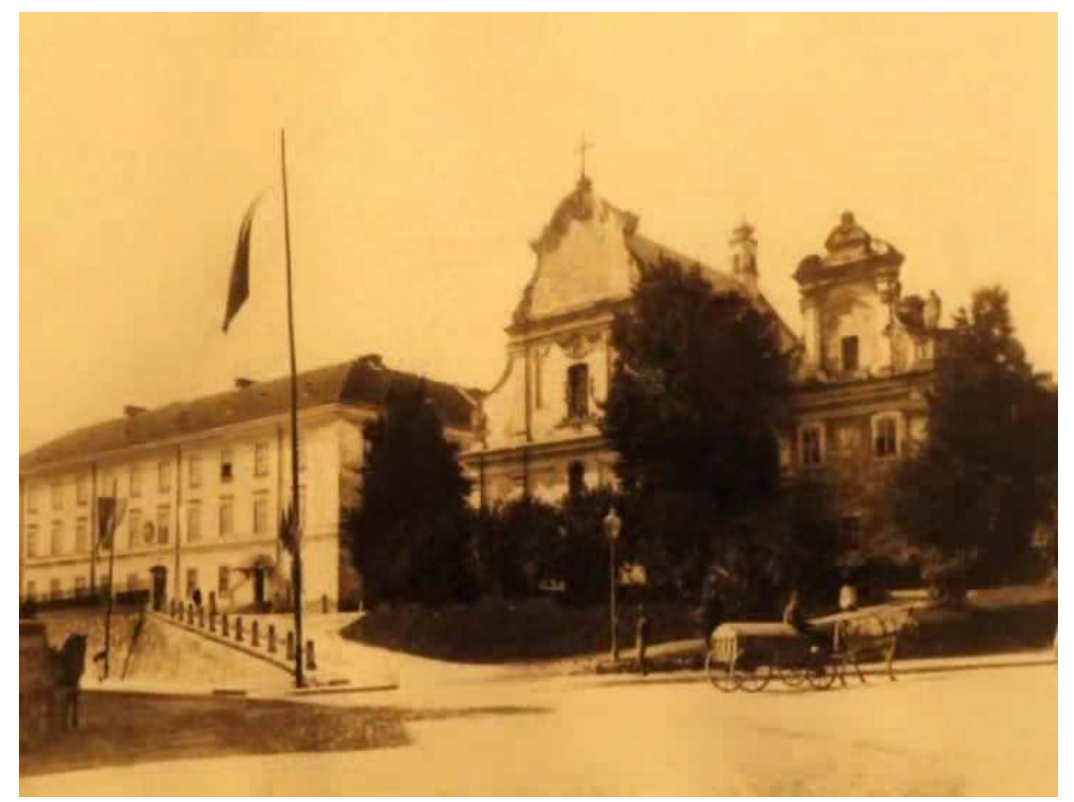

Figure 2. Photography of Mykolai Street in Lviv, dated around 1860s, with University building on the left.

One of the faculties of the Lviv University at that time was Medical Faculty, which existed since 1784. From 1851 till 1875, the medical school was represented as Medical-Surgical Institute, which included the Department of Anatomy headed by Prof. Planer. During that time two remaining papers [8, 9] known to be written by Planer were published.

In 1863 Julius Planer moved from Lviv to the city of Graz, now Republic of Austria, where from 1863 till 1881 he headed Chair of Department of Anatomy at Medical Faculty of the University of Graz. During years 1865-1876, Planer was several times reelected the Dean of the Medical Faculty at the same University, since, according to the University rules the Dean could be elected for the term of one year only. Professor Julius Planer died in Graz on 25th of July of 1881.

Scientific interests of Prof. Planer mainly included descriptive and topographical anatomy. He founded Museum of pathological-anatomy at Lviv University as well as enriched physiological and anatomical collections of the University. While working at Lviv University, in 1861 Planer also published a paper [9] in which he reported, as it was realized later, whatever first observation of the thermotropic liquid crystal state and isotropic/nematic phase behavior (see also the English translation of this article by Planer in present issue), acknowledged in many textbooks.

Another important Prof. Planer's study was on the occurrence of pigment granules in the blood, particularly in their relation to the course of intermittent fever [3, 8]. It is worth commenting that at that time the cause of malaria was unknown, relationship of pigment to the parasite was established in 1880, when the French physician Charles Louis Alphonse Laveran, observed pigmented parasites inside the red blood cells of people suffering from malaria. He witnessed the events of exflagellation and became convinced that the moving flagellae were parasitic microorganisms. Laveran was awarded the 1907 Nobel Prize for Physiology or Medicine "in recognition of his work on the role played by protozoa in causing diseases" 10. And thus, based on our current knowledge of plasmodium life cycle [11], we can suppose that both Rudolf Virchow in 1847 [12], Johann Meckel in 1948 [13], and Julius Planer in 1854 [3] were describing an asexually reproducing plasmodia inside red blood cells - the causative agent of malaria (which they referred to as intermittent fever) without recognizing it. 
Other well known papers authored by Prof. Planer are devoted to patho-anatomical study [4] and to the study of gases in biological fluids [8]. The life of Julius Planer is a wonderful example of a human genius that can greatly contribute to the development of science as a whole, without limiting oneself to a particular field of research.

\title{
Acknowledgements
}

The authors are grateful to Dr. S. Riznychok and Prof. M. Schmiel for their help in collecting archive documents. The support of OSA Foundation is also acknowledged.

\section{References}

1. Zimenkovsky B.S., Gzegotsky M.R., Lutsyk A.D. Professors of Danylo Halytsky National Medical University in Lviv: 1784-2006. Nautilus, Lviv, 2006 [in Ukrainian].

2. Österreichisches Biographiesches Lexikon 1815-1950. Wien, 1983 [in German].

3. Planer J. Über das Vorkommen von Pigment im Blute (Occurrence of the pigment in the blood), Wiener Zeitschrift, 1854, 127-139; 280-298.

4. Planer J. Statistik der Leichenkammer des k. k. akkgem. Krankenhauses von Monat November 1854. Zeitschrift der KK Gesellschaft der Ärzte zu Wien, Wochenblatt, 1855, 1, 171.

5. University of Graz web-site, www.uni-graz.at

6. Finkel L. Historia Universytetu Lwowskiego. Lwow, 1894 [in Polish].

7. Ivan Franko Lviv National University web-site www.lnu.edu.ua

8. Planer J., Gase des Harns und der Transsudate / Zeitschrift der K.k. Gesellschaft der Aerzte zu Wien, 1859, 30, 465-475.

9. Planer J., Notiz über das Cholestearin, Annalen der Chemie und Pharmacie, 1861, 118, 25-27.

10. http://en.wikipedia.org/wiki/History of malaria

11. Jones M.K., Good M.F., Nature Medicine, 2006, 12, 170-171.

12. Virchow R., Virchows Archiv, 1847, 1, 379-404; 407-486.

13. Lorber C.G., Lorber C.P., Schneider J., Hess Aerzteblatt, 2005, 2, 95-99.

\section{Короткий огляд життєвого шляху та наукової діяльності Юліуса Планера}

\author{
Р. Білий12, А. Луцик \\ 1 Інститут біології клітини Національної академії наук України, Львів, Україна \\ 2 Національний медичний університет ім. Данила Галицького, Львів, Україна
}

Представлено короткий огляд життєвого шляху та наукової діяльності Юліуса Планера. Професор Планер жив півтора сторіччя тому, проте його наукові дослідження, зокрема, протягом часу коли він очолював кафедру анатомії Львівського університету (зараз Львівський національний університет імені Івана Франка) стали визначальними на шляху сучасного розуміння рідких кристалів. Працюючи у Львівському університеті, Планер також зробив кілька значних відкриттів у біомедичній галузі.

Ключові слова: Юліус Планер, рідкий кристал, історія науки 
